\title{
ANALYSIS OF LOAD CAPACITY OF ROOF TRUSSES WITH IMPERFECTIONS AND THE ISSUE OF EQUIVALENT LOAD ADOPTION
}

\author{
Grzegorz Gremza', Jan Zamorowski ${ }^{2 \bowtie}$ \\ ${ }^{1}$ Faculty of Civil Engineering, Silesian University of Technology, Gliwice, Poland \\ ${ }^{2}$ Faculty of Materials, Civil and Environmental Engineering, University of Bielsko-Biala, Bielsko-Biała, Poland
}

\begin{abstract}
The internal forces and stresses were analyzed and utilization of the design resistance in selected members of the roof structure with local and global geometrical imperfections was evaluated. Values of these imperfections were based on the information given in the standards EN 1090-2 and EN 1993-1-1. Besides the basic reference model with imperfections, models without imperfections, with different equivalent load arrangements by the authors' own concept and comparatively according to the standard EN 1993-1-1 were analyzed. The calculations were made using the $1^{\text {st }}$ and the $2^{\text {nd }}$ order analysis. Conclusion concerning accuracy of the internal forces estimation and limit states check by use the equivalent load system proposed in the standard EN 1993-1-1 are presented. Deficiencies in the provisions of this standard in terms of adopting equivalent loads in roof structures with imperfections, resulting in underestimation of the stresses in the bottom chords of the roof trusses, has been demonstrated.
\end{abstract}

Key words: truss imperfections, equivalent load, $2^{\text {nd }}$ order analysis, limit state

\section{INTRODUCTION}

In currently available methods of steel structures analysis there are various possibilities of incorporating the geometrical imperfections consisting in the deviation of the main structural nodes from their designed position and the initial deformations of the individual member between nodes, as well as random eccentricities and residual stresses, which effects also may be replaced by the equivalent geometrical imperfection. Introduction of aforementioned imperfections into the geometry of the model, in particular bow imperfections, is laborious and sometimes inconvenient. For this reason, approximate methods consisting of selection of the equivalent load and calculations of buckling factors are usually applied. This paper presents the analysis of different options of equivalent loads adoption, regarding provisions specified in the standard EN 1993-1-1 (European Committee for Standardization [CEN], 2005), made to assess the accuracy of the internal forces and stresses calculation in individual rods of the roof structure.

\section{IMPERFECTIONS}

Steel buildings structures and the other steel supporting structures are characterized by deviation from their assumed shape. These geometrical imperfections can be divided into two main groups: initial deviations of the frame or truss nodes position and initial deformation 
of the individual rods on their length. A review concerning different methods of imperfections modelling has been presented earlier (Zamorowski \& Gremza, 2019). Residual stress remaining after the process of rolling or welding, as well as the stress unintentionally introduced during erection e.g. due to incorrect length of the rod, may be also considered as imperfections that influence the structure load capacity and should be incorporated into the design process. Residual stress are usually taken into account in simplified way by use of appropriate buckling curve or equivalent initial deformation of the individual rod.

\section{Permissible imperfections in accordance with the standard EN 1090-2}

Steel structures designed according to the standard EN 1993-1-1 should be executed and erected in accordance with the standard EN 1090-2 (CEN, 2018), which specifies selected values of essential (i.e. affecting the load capacity) manufacturing and erection tolerances of the structure that should not be exceeded. Within the essential manufacturing tolerances listed in the standard EN 1090-2, the following may be implemented in roof structure analysis: deviations from straightness of a press braked profile or a flange of a welded profile equal to $1 / 1,000$ distance between their restraints, deviations of panel points relative to lattice intended outline $\Delta= \pm L / 500$ but not less than $|\Delta|=12 \mathrm{~mm}$ (Fig. 1a), as well as deviation of truss braces (diagonals) and posts from straightness 1/1,000 of their length (but not less than $|\Delta|=4 \mathrm{~mm}$ ). In turn, within the essential erection tolerances, important is the deviation from the straightness of member subject to bending or compression equal to 1/750 of the length between restraints, as well as an angular misalignment
$\Delta \theta= \pm 1 / 500$ rad (Fig. 1b) in a full contact end bearing. Unfortunately, these deviations do not correspond exactly to the imperfections assumed for the design calculations based on the standard EN 1993-1-1.

\section{Global imperfections in accordance with the standard EN 1993-1-1}

The standard EN 1993-1-1 contains provisions for calculation of transverse roof bracings that ensure lateral support for the compressed chord of the roof girders e.g. truss. According to this standard, initial sinusoidal imperfections of the chord on the whole length of the truss, with amplitude $\left(e_{0}\right)$, is taken into account (Fig. 2a):

$$
e_{0}=\alpha_{m} L / 500
$$

Alternatively, possibility of kinking of the compressed members in the field joint due to angular misalignment by an angle $\phi=1 / 200 \mathrm{rad}$ is taken into account, resulting in the horizontal action (Fig. 2b):

$$
\alpha_{m} N_{\mathrm{Ed}} / 100
$$

In Formulas (1) and (2):

$$
\alpha_{m}=[0.5(1+1 / m)]^{0.5}
$$

where:

$m$ - number of trusses to be restrained,

$N_{\text {Ed }}$ - maximum axial force from all rods of the chord. a)

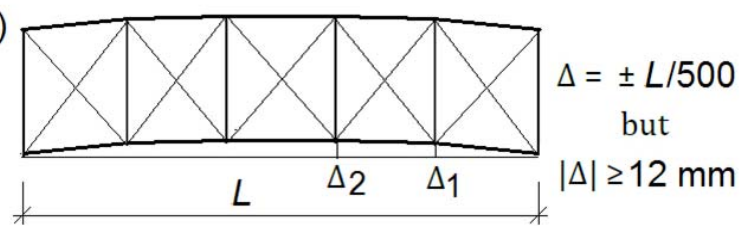

b) $\Delta \Theta / 2$

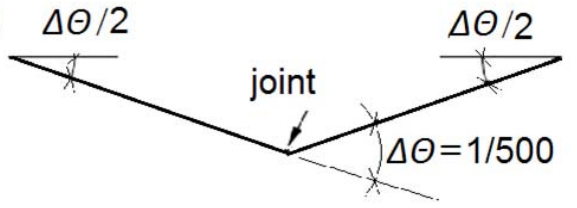

Fig. 1. Essential deviation according to standard EN 1090-2 in application to roof members: a - deviations of panel points; $b$ - angular misalignment of two rods in their contact 
a)

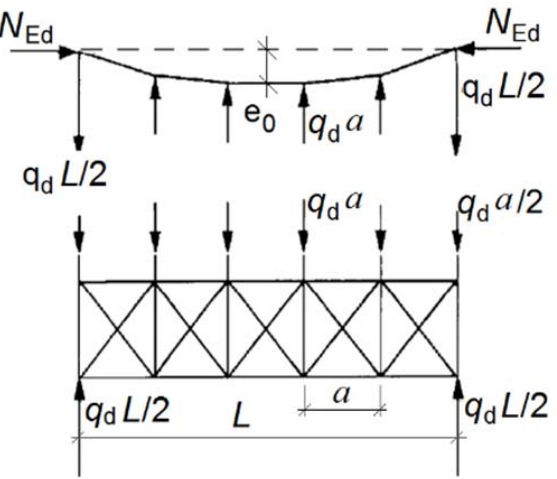

b)

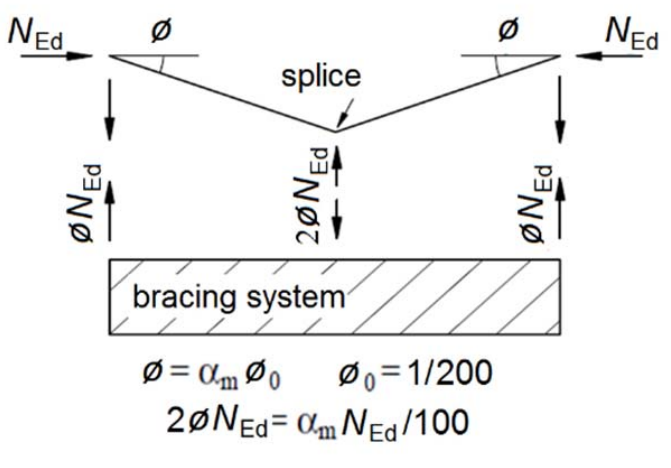

Fig. 2. Equivalent loads on bracing according to the standard EN 1993-1-1: a - due to bow imperfection of bracing system; $\mathrm{b}$ - due to angular rods misalignment at the splice

\section{Local bow imperfections}

Direct forming of initial bow deformation of the rod relative to its theoretical axis is rarely implemented into calculation models. However, their implementation allows a better estimation of internal forces distribution in both lattice and frame structures as well as more accurate estimation of the spatial rigidity and displacements of these structures, since the initial and elastic bending determines stiffness of the rod. Effective stiffness $-(E A)_{\text {eq }}$ of the rod with initial bow imperfection, if considered straight, may be calculated as in Formula (4):

$$
(E A)_{\mathrm{eq}}=\frac{N_{\mathrm{Ed}} l}{\Delta l_{\mathrm{A}}+\Delta l_{\text {bow }}} \leq E A
$$

where:

$N_{\text {Ed }}-$ axial force,

$l \quad-$ length of the rod,
$\Delta l_{\mathrm{A}}-$ shortening of the rod resulting from the compression of the section (Fig. 3),

$\Delta l_{\text {bow }}$ - shortening of the rod resulting from its bow deformation (Fig. 3),

E - Young modulus,

A $\quad$ - cross-sectional area.

In the paper by Niewiadomski and Zamorowski (1987) it has been demonstrated that the noticeable influence of compression on the effective stiffness of the rod with imperfection becomes visible at slenderness $\lambda>100$. This effect is greater for larger axial force value and less significant for small value of this force (see Fig. 3, in which the influence of compression force intensity on the effective stiffness of twopinned rods in function of their slenderness has been illustrated). Model for analysis of structures with more complex initial rods deformations was presented in Zamorowski (2013).

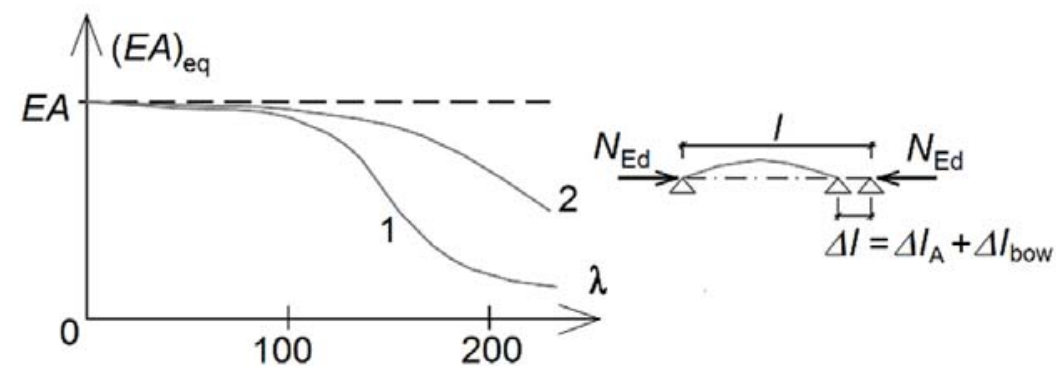

Fig. 3. Two-pinned, initially bended rod and equivalent stiffness along its chord between end nodes: $1-$ values of $N_{\text {Ed }}$ about $90 \%$ design resistance; 2 - about $10 \%$ 
Initial bow imperfections given by the standard EN 1993-1-1 not only reflect the initial deformations of the rods axes between nodes, but also replace the effects of the residual rolling and welding stresses as well as the unintentional eccentricities of the rods attachments or unintentional eccentricities of external loads. The use of initial bow imperfection in combination with the $2^{\text {nd }}$ order analysis allows the calculation of the buckling factor to be omitted.

If the designer has no opportunity to introduce bow imperfections into the model, or it would be too labor-intensive due to the number of rods in the structure, forces redistribution between members in tension and in compression can be roughly estimated using an alternative method, where, in the first step, the cross-sectional area $(A)$ of compressed members, in which the design resistance was found to be exceeded, are reduced by the buckling factor, $A_{\text {red, } 1}=\chi_{\min } A$, and in the subsequent steps, a further correction of the cross-sectional area is made so that $N_{\mathrm{Ed}}=A_{\text {red,2 }} f_{\mathrm{y}}$. Such approach implementation in analysis of a large sports and entertainment facility building has been mentioned by the authors in their earlier publication (Zamorowski \& Gremza, 2009).

\section{Imperfections adopted in this work}

In the following sections of this work, the following imperfections were taken into account: initial sinusoidal imperfection of the top chord with amplitude $L / 500$ as in Figure 2a, and kinking of the bottom chord $\Delta \theta= \pm 1 / 500 \mathrm{rad}$ according to the standard EN 1090-2 as in Figure 1b. For simplifying, sinusoidal imperfection of the top chord was replaced by the polygonal chain. Additionally, bow imperfections in the minor axis of compressed chord rods, equal to $1 / 200$ of their theoretical lengths in plane of the truss, were considered (buckling curve "c" according to the standard EN 1993-1-1 is adopted). Imperfections of bracings were also taken into account. It was assumed that the trapezoidal sheet stops the increase of initial lateral deformations of purlins due to lateral-torsional buckling, therefore initial bow imperfection for these members was not introduced into the model.

\section{PRECISE EQUIVALENT LOAD SUBSTITUTING GLOBAL IMPERFECTIONS}

The equivalent load that allows to precisely substitute the effects of global imperfections is the group of lateral forces applied in nodes of the upper and the lower chords of all trusses, that results from the change of the inclination of the rods relative to the truss theoretical plane and axial forces in these rods (Fig. 4).

Equivalent forces in "precise" approach may be calculated from the formula (see Fig. 4c):

$$
F_{\text {eq }}=N_{\mathrm{Ed}} \sin \alpha \cos \beta
$$

where:

$N_{\mathrm{Ed}}$ - force obtained from the model without imperfection,

$\alpha, \beta-$ angles.

In Columns 6 and 7 of Table 1 the resultant lateral forces (equivalent forces $-F_{\text {eq }}$ ) applied to nodes of the exemplary truss, and in Columns $8-11$ of these a)

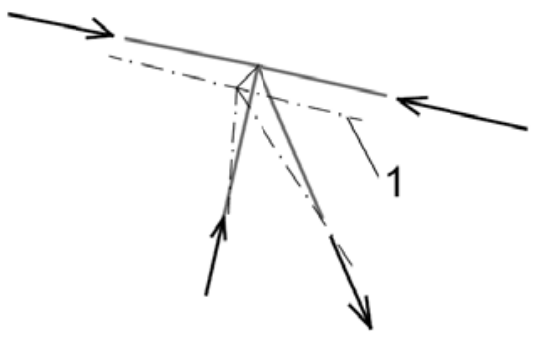

b)

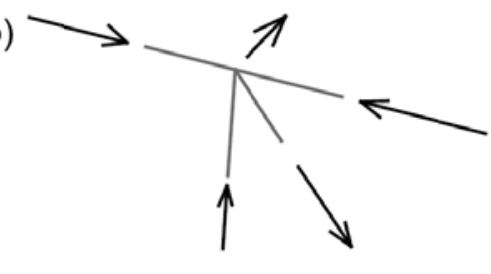

c)

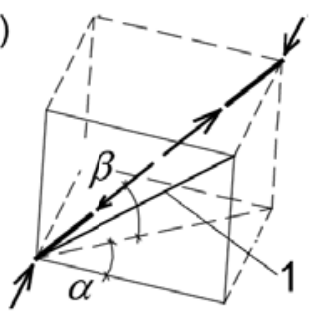

Fig. 4. Equivalent load at the truss node replacing global imperfection ( $P-\Delta$ effects for rods): a - a node of the truss with imperfection; $\mathrm{b}$ - the perfect one with equivalent load, $\mathrm{c}$ - equivalent load assuming tilting of the rod out of the assumed plane; 1 - intended geometry 
table reactions, are collected. Lateral deviation $\left(\Delta_{\text {top }}\right.$ and $\Delta_{\text {bot }}$ ) of the truss nodes from its intended plane, resulting from global imperfection of the truss chords (Fig. 5), are given in Columns 2 and 3. As can be seen, lateral reactions transferred from the twisted truss and from the perfect truss loaded by equivalent forces are of almost identical value. The presented results prove that in the model of the perfect structure, analogous forces and displacements as in the model with global imperfection may be successfully obtained. Although calculations of spatially deformed structures according to the presented approach allow to obtain satisfactory and reasonable results, they may be regarded too time-consuming by the designers. Hence, simplified variants of the equivalent loads were analysed later in this work.

Table 1. Out of plane tilts of posts of analysed truss, lateral reactions and equivalent actions

\begin{tabular}{|c|c|c|c|c|c|c|c|c|c|c|}
\hline \multirow{3}{*}{$\begin{array}{l}\text { Distance } \\
\text { from } \\
\text { the truss } \\
\text { support } \\
\text { [m] }\end{array}$} & \multirow{2}{*}{\multicolumn{4}{|c|}{$\begin{array}{l}\text { Imperfect geometry } \\
\text { (acc. to Fig. 5) }\end{array}$}} & \multirow{2}{*}{\multicolumn{2}{|c|}{$\begin{array}{c}\text { Equivalent load } \\
\text { in nodes }\left(F_{\mathrm{eq}}\right) \\
{[\mathrm{kN}]}\end{array}$}} & \multicolumn{4}{|c|}{$\begin{array}{l}\text { Lateral reactions in nodes } \\
\qquad[\mathrm{kN}]\end{array}$} \\
\hline & & & & & & & \multicolumn{2}{|c|}{ imperfect model } & \multicolumn{2}{|c|}{ perfect model $^{\mathrm{a}}$} \\
\hline & $\begin{array}{l}\Delta_{\text {top }} \\
{[\mathrm{cm}]}\end{array}$ & $\begin{array}{l}\Delta_{\text {bot }} \\
{[\mathrm{cm}]}\end{array}$ & $\begin{array}{l}h_{\text {post }} \\
{[\mathrm{cm}]}\end{array}$ & $\begin{array}{c}\phi \\
{[\mathrm{rad}]}\end{array}$ & $\begin{array}{l}\text { top } \\
\text { chord }\end{array}$ & $\begin{array}{l}\text { bottom } \\
\text { chord }\end{array}$ & top chord & $\begin{array}{l}\text { bottom } \\
\text { chord }\end{array}$ & top chord & $\begin{array}{l}\text { bottom } \\
\text { chord }\end{array}$ \\
\hline 1 & 2 & 3 & 4 & 5 & 6 & 7 & 8 & 9 & 10 & 11 \\
\hline 0 & 0.00 & 0.00 & - & - & -1.027 & - & 0.951 & 0.684 & 0.950 & 0.686 \\
\hline 3 & -1.84 & 0.30 & 222 & 0.0096 & 0.005 & -0.911 & 0.119 & - & 0.121 & - \\
\hline 6 & -3.39 & 0.60 & 248 & 0.0161 & 0.766 & -0.375 & -0.678 & - & -0.676 & - \\
\hline 9 & -4.43 & 0.90 & 274 & 0.0195 & 1.147 & -0.086 & -1.239 & - & -1.237 & - \\
\hline 12 & -4.80 & 1.20 & 300 & 0.0200 & 0.442 & 0.503 & -0.511 & 0.838 & -0.511 & 0.842 \\
\hline
\end{tabular}

${ }^{\mathrm{a}}$ With equivalent load as in Columns 6 and 7.

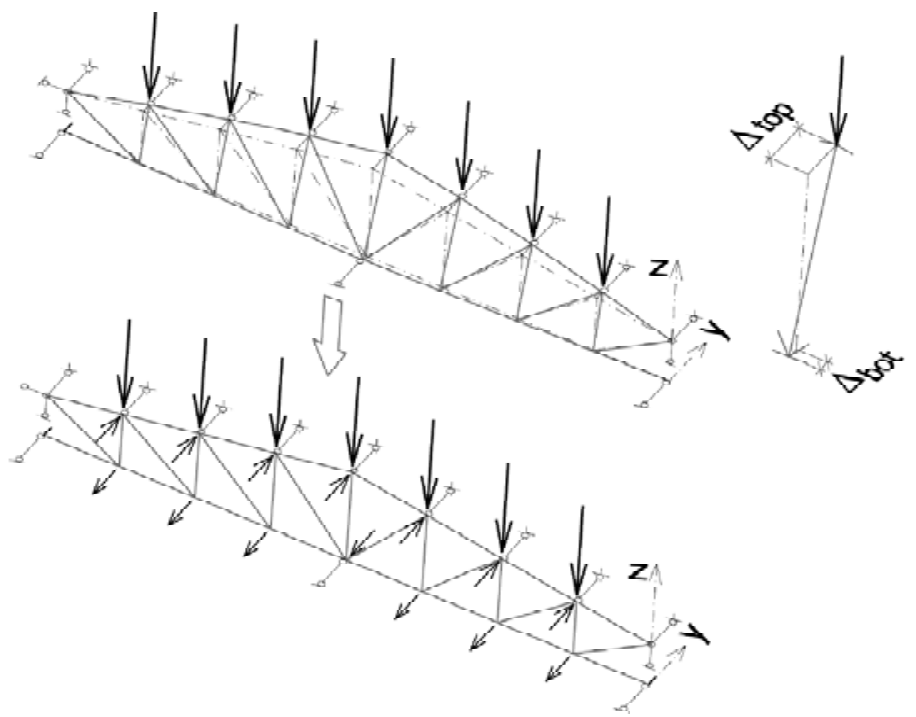

Fig. 5. Replacement of initially deformed truss by the ideal truss with equivalent loads, resulting from the change of inclination of all the rods relative to the vertical plane of the truss 


\section{MODELLING OF EXEMPLARY 3D STRUCTURE}

\section{The roof arrangement and construction}

To avoid a problem with interpretation of the standard EN 1090-2, as well as unnecessary calculation effort, the analyzed system was limited to a pair of trusses spaced at a distance of $6.0 \mathrm{~m}$, linked together by means of purlins and bracings (Fig. 6). Every truss is of a maximum height of $3.0 \mathrm{~m}$, span of $24.0 \mathrm{~m}$ with the slope of the top chord of $5^{\circ}$. Chords of the truss were designed from $1 / 2$ HEB 220, posts and diagonals from RHS $100 \times 100 \times 4$ profiles. Chords were considered continuous, except for the end-plate field bolted joints located in vertical plane passing the ridge, but assumed fully rigid. Vertical roof bracings type $\mathrm{K}$ in the ridge plane were designed of $2 L 60 \times 60 \times 6$, and transverse roof bracings diagonals type $\mathrm{X}$ as $L 60 \times 60 \times 6$. Purlins were planned as IPE180 beams. The load-bearing element supporting the roof covering is a trapezoidal sheet protecting the purlins from lateral torsional and flexural buckling. The total weight of the roof covering was $0.49 \mathrm{kN} \cdot \mathrm{m}^{-2}$ and the snow design load was $1.44 \mathrm{kN} \cdot \mathrm{m}^{-2}$. Connections between the ends of the bottom chords and the columns were designed in a way that prevents the transmission of any axial force, but provides lateral support.

\section{Slender diagonals of transverse roof bracings}

Diagonals of roof bracing with X-arrangement are commonly designed relatively slender, by an assumption that the horizontal load is transferred only by the tensioned diagonal in each X-pair. On the other hand, if the gravity load is dominant, then compression forces in all diagonals will occur and the purlins will be tensioned.
In such a case, if diagonals are treated as the elements being able to transfer tension forces only, they will be removed from the model. It means that the upper chords of the roof truss are deprived of lateral support and the structure becomes temporarily unstable. As a result, no convergence can be achieved in the $2^{\text {nd }}$ order analysis using popular computer programs. For this reason, initial bow imperfections of all diagonals, equal to $1 / 250$ of their length (respective to buckling curve "c" according to the standard EN 1993-1-1), was adopted, without excluding them from cooperation with the rest of the structure in any load combination.

\section{Reference non-linear models with global imperfections}

In a reference model $\mathrm{N} 1$, the adopted global imperfections of the trusses chords and the local bow imperfections of compressed rods were directly introduced into the model geometry. Local bow imperfections of the compressed rods were introduced according to the buckling curves defined in the standard EN 1993-1-1 and the expected buckling direction. In model N1s, in comparison to the basic model N1, bottom chords were straight (deviations resulting from the angle misalignment in the joints of the lower chords of all trusses, $\Delta \theta= \pm 1 / 500 \mathrm{rad}$, were omitted). The calculations were made taking into account the $2^{\text {nd }}$ order effects.

\section{Models with different equivalent loads substituting global imperfections}

Two nonlinear models with equivalent loads were analyzed. In model N2s (with straight bottom chord), the global imperfections of the upper chords were replaced

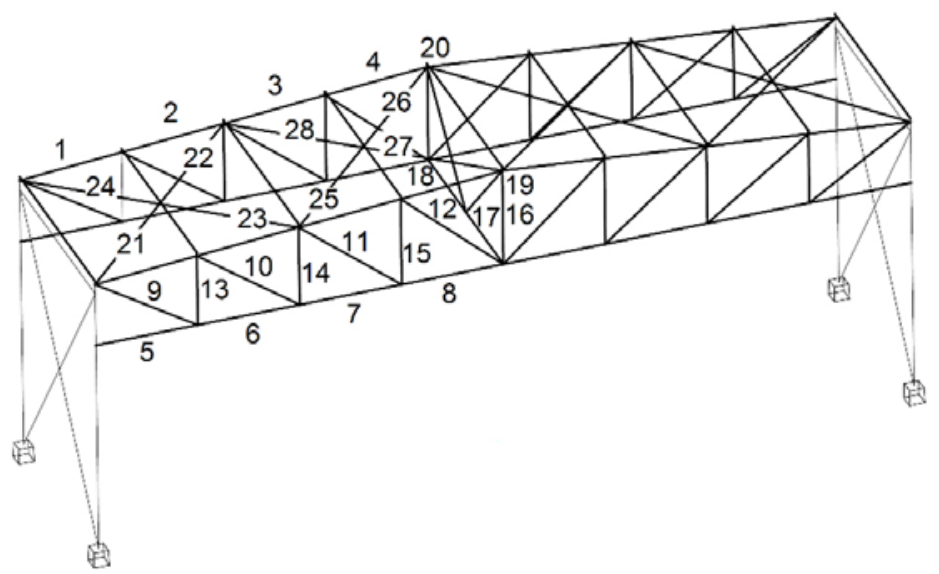

Fig. 6. Spatial structure analyzed in this work 
by the $\Delta H_{\text {top }}$ forces applied in the nodes of the upper chords (Fig. 7a). These forces were calculated on the basis of the actions transferred from purlins to these nodes and tilting of posts out of the planes of trusses, analogous to the of $P-\Delta$ effect in frames (Niewiadomski \& Zamorowski, 2017). In model N3s, the lateral forces $\Delta H_{\text {top }}$ and additionally opposite directed lateral forces $\Delta H_{\mathrm{bot}}$ in nodes of the lower chords were taken into account (Fig. 7b). The sum of these forces is equal to zero (they create a self-balanced system).

In linear model L1 both the local and the global imperfections were omitted, and the equivalent load applied to the top truss nodes was calculated from the formula:

$$
Q_{\mathrm{d}}=q_{\mathrm{d}} a=\frac{8 N_{\mathrm{Ed}}\left(e_{0}+\delta\right)}{L^{2}} a
$$

where:

$N_{\text {Ed }}$ - maximum compression force in the top chord,

$e_{0}$ - initial global lateral deflection - see Formula (1),

$\delta$ - horizontal displacement of the upper chord (in the first step is equal to zero),
$L$ - span of the truss,

a - distance between truss nodes as in Figure 2a.

Loading forces accaccording to Formula (6) were balanced by reaction applied to the end points of the chord (see Fig. 2a).

In model L2, to the upper chords the forces $Q_{\mathrm{d}}=Q_{\mathrm{d}, \text { top }}$ calculated by Formula (6), and in the bottom chord the opposite directed loads, $Q_{\mathrm{d} \text {,bot }}=-Q_{\mathrm{d} \text {,top }}$, were applied, similarly to $\Delta H_{\text {top }}$ and $\Delta H_{\text {bot }}$ application. More complicated approach may be also used, where horizontal loads in perfect model are specified to obtain displacements equal to the imperfection in unloaded imperfect model (Piątkowski, 2017).

\section{Comparative models without both global imperfection and equivalent loads}

For comparison purpose, two models without global imperfections as well as without equivalent loads were analyzed. Only in nonlinear model $\mathrm{N}$ bow imperfections were introduced. List of analysed models are in Table 2.
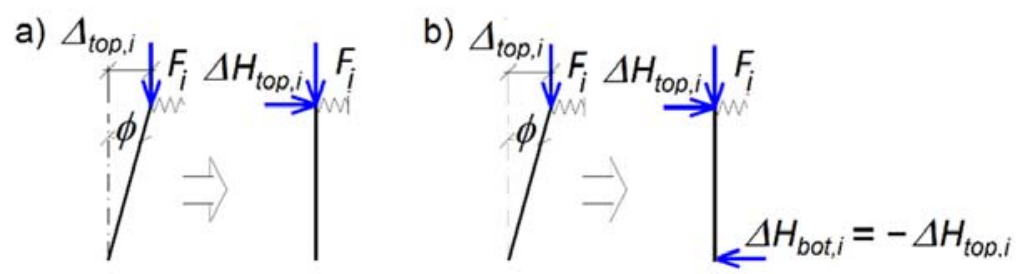

Fig. 7. Tilting of the truss posts and equivalent loads: $a-$ in model N2s; $b-$ in model N3s

Table 2. List of analysed models and their features

\begin{tabular}{|c|c|c|c|c|c|c|c|c|}
\hline \multirow{2}{*}{ Model feature } & \multicolumn{8}{|c|}{ Model name } \\
\hline & N1 & N1s & $\mathrm{N} 2 \mathrm{~s}$ & $\mathrm{~N} 3 \mathrm{~s}$ & L1 & $\mathrm{L} 2$ & $\mathrm{~N}$ & $\mathrm{~L}$ \\
\hline Global imperfection & $\mathrm{Y}$ & $\mathrm{Y}$ & - & - & - & - & - & - \\
\hline Only $\Delta H_{\text {top }}$ & - & - & $\mathrm{Y}$ & - & - & - & - & - \\
\hline$\Delta H_{\text {top }}$ and $\Delta H_{\text {bot }}=-\Delta H_{\text {top }}$ & - & - & - & $\mathrm{Y}$ & - & - & - & - \\
\hline$Q_{\mathrm{d}}$ acc. to EN 1993-1-1 & - & & - & - & $\mathrm{Y}$ & - & - & - \\
\hline$Q_{\mathrm{d}, \text { top }}=Q_{\mathrm{d}}$ and $Q_{\mathrm{d}, \mathrm{bot}}=-Q_{\mathrm{d}}$ & - & - & - & - & - & $\mathrm{Y}$ & - & - \\
\hline $1^{\text {st }}$ order analysis & - & - & - & - & $\mathrm{Y}^{\mathrm{a}}$ & $\mathrm{Y}^{\mathrm{a}}$ & - & $\mathrm{Y}$ \\
\hline $2^{\text {nd }}$ order analysis & $\mathrm{Y}$ & Y & $\mathrm{Y}$ & $\mathrm{Y}$ & - & - & $\mathrm{Y}$ & - \\
\hline Bow imperfections of rods in compression & $\mathrm{Y}$ & $\mathrm{Y}$ & $\mathrm{Y}$ & $\mathrm{Y}$ & - & - & $\mathrm{Y}$ & - \\
\hline
\end{tabular}

${ }^{a}$ Displacements according to Formula (6) are included - displacement $(\delta)$ did not exceed $3.9 \%$ of $e_{0}$. 
Gremza, G., Zamorowski, J. (2021). Analysis of load capacity of roof trusses with imperfections and the issue of equivalent load adoption. Acta Sci. Pol. Architectura, 20 (1), 65-76. doi: 10.22630/ASPA.2021.20.1.7

\section{RESULTS}

\section{Internal forces and utilization of the design resistance}

In Tables 3 and 4 the results of calculations are collected. Table 3 presents values of the axial forces obtained for individual rods of the roof structure by use of the calculation models mentioned in previous section: in trusses, transverse roof bracings and vertical roof bracings. The forces in rods described as $1-16$ were the bigger forces from two trusses. Columns $3-10$ of Table 4 present utilization ratios $\left(R_{i}\right)$ of the truss rods design resistance (load capacities).

Table 3. Axial forces $N_{\mathrm{Ed}, i}[\mathrm{kN}]$ in rods

\begin{tabular}{|c|c|c|c|c|c|c|c|c|c|}
\hline \multirow{2}{*}{\multicolumn{2}{|c|}{$\begin{array}{l}\text { Rod number } \\
\text { (acc. to Fig. 6) }\end{array}$}} & \multicolumn{2}{|c|}{ Reference } & \multicolumn{4}{|c|}{ With equivalent loads } & \multicolumn{2}{|c|}{ Globally perfect } \\
\hline & & N1 & N1s & $\mathrm{N} 2 \mathrm{~s}$ & $\mathrm{~N} 3 \mathrm{~s}$ & L1 & L2 & $\mathrm{N}^{\mathrm{a}}$ & $\mathrm{L}$ \\
\hline 1 & 2 & 3 & 4 & 5 & 6 & 7 & 8 & 9 & 10 \\
\hline 1 & \multirow{4}{*}{ top chord } & -174.2 & -173.8 & -174.4 & -174.5 & -174.3 & -174.1 & -173.2 & -173.1 \\
\hline 2 & & -267.0 & -267.4 & -266.9 & -268.8 & -267.1 & -268.7 & -266.2 & -266.2 \\
\hline 3 & & -303.9 & -302.9 & -304.8 & -306.3 & -303.9 & -304.9 & -302.3 & -301.2 \\
\hline 4 & & -297.5 & -296.9 & -298.9 & -301.7 & -296.6 & -298.9 & -296.7 & -294.2 \\
\hline 5 & \multirow{4}{*}{ bottom chord } & 0.0 & 0.0 & 0.0 & 0.0 & 0.0 & 0.0 & 0.0 & 0.0 \\
\hline 6 & & 174.8 & 174.9 & 174.0 & 175.2 & 173.4 & 174.7 & 173.5 & 172.9 \\
\hline 7 & & 268.3 & 268.5 & 266.8 & 268.9 & 266.6 & 268.9 & 265.9 & 265.7 \\
\hline 8 & & 305.2 & 305.4 & 303.1 & 305.9 & 302.2 & 305.3 & 301.8 & 301.0 \\
\hline 9 & \multirow{4}{*}{ truss braces } & 205.8 & 205.7 & 206.8 & 205.4 & 205.9 & 204.4 & 207.4 & 206.5 \\
\hline 10 & & 114,9 & 114.8 & 115.8 & 114.6 & 115.0 & 113.7 & 116.3 & 115.4 \\
\hline 11 & & 45.4 & 45.4 & 46.2 & 45.2 & 45.4 & 44.4 & 46.6 & 45.8 \\
\hline 12 & & -14.4 & -14.4 & -13.7 & -14.5 & -9.8 & -10.7 & -13.3 & -9.4 \\
\hline 13 & \multirow{4}{*}{ truss posts } & -114.4 & -114.5 & -113.8 & -114.6 & -113.3 & -114.1 & -113.5 & -113.0 \\
\hline 14 & & -70.3 & -70.3 & -69.7 & -70.5 & -69.0 & -69.7 & -69.4 & -68.7 \\
\hline 15 & & -31.0 & -31.0 & -30.5 & -31.1 & -29.5 & -30.2 & -30.2 & -29.3 \\
\hline 16 & & 16.5 & 16.4 & 17.3 & 16.4 & 12.3 & 11.1 & 17.9 & 12.8 \\
\hline 17 & \multirow{4}{*}{$\begin{array}{l}\text { ridge } \\
\mathrm{K} \text { bracings }\end{array}$} & 1.2 & 1.5 & 0.1 & 2.6 & 0.0 & 2.7 & 0.0 & 0.0 \\
\hline 18 & & -1.3 & -1.6 & -0.1 & -2.6 & 0.1 & -2.6 & 0.0 & 0.0 \\
\hline 19 & & -1.7 & -2.2 & -0.1 & -3.7 & 0.0 & -3.8 & 0.0 & 0.0 \\
\hline 20 & & 1.8 & 2.2 & 0.1 & 3.7 & 0.0 & 3.8 & 0.0 & 0.0 \\
\hline 21 & \multirow{8}{*}{$\begin{array}{c}\text { roof bracings } \\
\text { diagonals }\end{array}$} & 3.1 & 2.6 & 2.2 & 0.4 & 2.2 & 0.7 & -0.4 & -0.3 \\
\hline 22 & & 4.6 & 3.9 & 2.6 & 0.9 & 2.0 & 0.5 & -0.6 & -0.3 \\
\hline 23 & & -4.2 & -3.7 & -2.8 & -1.4 & -2.6 & -1.2 & -0.3 & -0.3 \\
\hline 24 & & -2.9 & -2.6 & -2.5 & -1.0 & 2.8 & -1.4 & -0.4 & -0.3 \\
\hline 25 & & -0.3 & -0.5 & 0.5 & -1.5 & -0.3 & -2.1 & -0.2 & -1.0 \\
\hline 26 & & -0.6 & -0.7 & 0.5 & -1.4 & -0.5 & -2.2 & -0.4 & -1.1 \\
\hline 27 & & -0.2 & 0.3 & -0.8 & 1.3 & -1.6 & 0.1 & -0.3 & -1.1 \\
\hline 28 & & -0.4 & 0.3 & -0.9 & 1.5 & -1.8 & 0.0 & -0.4 & -1.0 \\
\hline
\end{tabular}

${ }^{a}$ But with local bow imperfection. 
Gremza, G., Zamorowski, J. (2021). Analysis of load capacity of roof trusses with imperfections and the issue of equivalent load adoption. Acta Sci. Pol. Architectura, 20 (1), 65-76. doi: 10.22630/ASPA.2021.20.1.7

Table 4. Utilization ratio $\left(R_{i}\right)$ of the rod design resistance [\%] for steel S355

\begin{tabular}{|c|c|c|c|c|c|c|c|c|c|}
\hline \multirow{2}{*}{\multicolumn{2}{|c|}{$\begin{array}{l}\text { Rod number } \\
\text { (acc. to Fig. 6) }\end{array}$}} & \multicolumn{2}{|c|}{ Reference } & \multicolumn{4}{|c|}{ With equivalent loads } & \multicolumn{2}{|c|}{ Globally perfect } \\
\hline & & N1 & N1s & $\mathrm{N} 2 \mathrm{~s}$ & N3s & L1 & L2 & $\mathrm{N}^{\mathrm{a}}$ & $\mathrm{L}$ \\
\hline 1 & \multirow{4}{*}{ top chord } & 0.485 & 0.483 & 0.486 & 0.488 & 0.370 & 0.370 & 0.482 & 0.367 \\
\hline 2 & & 0.651 & 0.651 & 0.654 & 0.660 & 0.567 & 0.570 & 0.650 & 0.565 \\
\hline 3 & & 0.693 & 0.690 & 0.696 & 0.703 & 0.645 & 0.647 & 0.689 & 0.639 \\
\hline 4 & & 0.750 & 0.748 & 0.752 & 0.760 & 0.629 & 0.634 & 0.745 & 0.624 \\
\hline 5 & \multirow{4}{*}{ bottom chord } & 0.055 & 0.049 & 0.017 & 0.030 & 0.015 & 0.041 & 0.017 & 0.015 \\
\hline 6 & & 0.158 & 0.152 & 0.115 & 0.138 & 0.113 & 0.148 & 0.114 & 0.112 \\
\hline 7 & & 0.194 & 0.190 & 0.173 & 0.191 & 0.171 & 0.205 & 0.171 & 0.170 \\
\hline 8 & & 0.241 & 0.233 & 0.196 & 0.238 & 0.194 & 0.257 & 0.194 & 0.192 \\
\hline 9 & \multirow{4}{*}{ truss braces } & 0.387 & 0.388 & 0.387 & 0.388 & 0.384 & 0.387 & 0.384 & 0.383 \\
\hline 10 & & 0.218 & 0.218 & 0.216 & 0.219 & 0.215 & 0.217 & 0.216 & 0.214 \\
\hline 11 & & 0.089 & 0.089 & 0.087 & 0.089 & 0.086 & 0.088 & 0.086 & 0.085 \\
\hline 12 & & 0.045 & 0.045 & 0.043 & 0.046 & 0.050 & 0.055 & 0.042 & 0.048 \\
\hline 13 & \multirow{4}{*}{ truss posts } & 0.299 & 0.300 & 0.299 & 0.300 & 0.302 & 0.305 & 0.297 & 0.302 \\
\hline 14 & & 0.188 & 0.189 & 0.187 & 0.189 & 0.200 & 0.202 & 0.186 & 0.199 \\
\hline 15 & & 0.085 & 0.085 & 0.083 & 0.085 & 0.094 & 0.096 & 0.082 & 0.093 \\
\hline 16 & & 0.036 & 0.036 & 0.034 & 0.036 & 0.025 & 0.027 & 0.033 & 0.024 \\
\hline
\end{tabular}

${ }^{a}$ But with local bow imperfection.

In linear models, calculation of $R_{i}$ of rods in compression were made according to the formula:

$$
R_{i}=\frac{N_{\mathrm{Ed}, i}}{\chi_{\min } A f_{\mathrm{y}} / \gamma_{\mathrm{M} 1}}
$$

In nonlinear models with bow imperfections the utilization ratio was estimated on the basis of the ratio of the maximum stress in the rod (regarding axial forces and $2^{\text {nd }}$ order bending) to the design yield strength:

$$
R_{i}=\frac{\sigma_{\mathrm{max}, i}}{f_{\mathrm{y}} / \gamma_{\mathrm{M} 0}}
$$

In Formulas (7) and (8):

$N_{\mathrm{Ed}, i} \quad-$ axial force in $i$-th rod,

$\chi_{\text {min }}-$ buckling coefficient,

A - cross-sectional area,

$f_{\mathrm{y}} \quad-$ yield strength,

$\sigma_{\max , i}-$ maximum stress in $i$-th rod,

$\gamma_{\mathrm{M} 0,} \gamma_{\mathrm{M} 1}-$ partial material factors in accordance with the standard EN 1993-1-1 (value of 1.0 is adopted).
The buckling coefficient $\left(\chi_{\min }\right)$ was calculated assuming the buckling length equal to the theoretical length of the rod between restraints in particular direction. In case of weak lateral support of the truss chord, instead of typical buckling check, more advanced analysis of the imperfect truss global stability could be introduced (Krajewski \& Iwicki, 2015)

For all rods in tension, regardless of the calculation model, Formula (8) was used.

\section{Lateral bending in the bottom chord of the truss}

In spatial structure of the roof with imperfections, horizontal bending of the bottom chords of trusses occur. This phenomenon is not taken into account in the analysis of the structure performed in accordance with design standards, e.g. the standard EN-1993-1-1. Table 5 presents values of stress in the bottom chord, obtained in calculations. The value to the left of the slash is the value of the tensile stress related to the axial forces and the second value, right to the slash, is the value of lateral bending stress. As can be seen, lateral bending (i.e. in horizontal plane) of the chord 
Gremza, G., Zamorowski, J. (2021). Analysis of load capacity of roof trusses with imperfections and the issue of equivalent load adoption. Acta Sci. Pol. Architectura, 20 (1), 65-76. doi: 10.22630/ASPA.2021.20.1.7

Table 5. Stress in rods of bottom chord [MPa]: from axial force $N_{\mathrm{Ed}, i} /$ from bending moment $M_{\mathrm{z}, i}$

\begin{tabular}{lcccccccc}
\hline \multirow{2}{*}{$\begin{array}{l}\text { Rod number } \\
\text { (acc. to Fig. 6) }\end{array}$} & \multicolumn{2}{c}{ Reference } & \multicolumn{3}{c}{ With equivalent loads } & \multicolumn{3}{c}{ Globally perfect } \\
\cline { 2 - 9 } & $\mathrm{N} 1$ & $\mathrm{~N} 1 \mathrm{~s}$ & $\mathrm{~N} 2 \mathrm{~s}$ & $\mathrm{~N} 3 \mathrm{~s}$ & $\mathrm{~L} 1$ & $\mathrm{~L} 2$ & $\mathrm{~N}^{\mathrm{a}}$ & $\mathrm{L}$ \\
\hline 5 & $0 / 18.5$ & $0 / 16.0$ & $0 / 1.3$ & $0 / 9.5$ & $0 / 0.7$ & $0 / 15.6$ & $0 / 1.4$ & $0 / 0.6$ \\
6 & $38.4 / 16.7$ & $38.5 / 14.3$ & $38.2 / 0.9$ & $38.5 / 8.6$ & $38,1 / 0.4$ & $38,4 / 14.6$ & $38,1 / 0.9$ & $38.0 / 0.4$ \\
7 & $59.0 / 8.4$ & $59.0 / 7.1$ & $58.6 / 0.8$ & $59.1 / 7.8$ & $58,6 / 0.6$ & $59,2 / 15.0$ & $58.4 / 0.5$ & $58.4 / 0.5$ \\
8 & $67.1 / 18.0$ & $67.1 / 15.1$ & $66.6 / 1.1$ & $67.2 / 16.6$ & $66.5 / 0.7$ & $67,2 / 27.3$ & $66.3 / 0.6$ & $66.2 / 0.4$ \\
\hline
\end{tabular}

${ }^{\text {a }}$ But with local bow imperfection.

causes a significant increase in stress compared to the pure axial tension. If the equivalent load is applied only in the plane of the roof (upper chords), the bending effect of the bottom chord will be underestimated, similarly to the model $\mathrm{N}$ and the model $\mathrm{L}$.

\section{DISCUSSION}

The calculation results shows that the values of the maximum axial forces in chords of the trusses obtained from the model N1 differ from the forces obtained from the other models no more than $1.39 \%$ (Tables 3 and 6). However, practical agreement of ultimate limit state conditions in the bottom chord with reference models $\mathrm{N} 1$ and N1s was obtained only in models N3s and L2, with equivalent load applied both to the upper and the lower chord (Table 4). In models N2s and L1 without global imperfections and with equivalent loads applied only to the upper chord, the utilization ratio of the design resistance is significantly underestimated and very similar to the models $\mathrm{N}$ and $\mathrm{L}$. That indicates the problem with correct check of the bottom trusses chords when

Table 6. Differences of axial forces $N_{\mathrm{Ed}, i}[\%]$ in comparison to model N1

\begin{tabular}{|c|c|c|c|c|c|c|c|c|}
\hline \multirow{2}{*}{$\begin{array}{l}\text { Rod number } \\
\text { (acc. to Fig. 6) }\end{array}$} & \multicolumn{2}{|c|}{ Reference } & \multicolumn{4}{|c|}{ With equivalent loads } & \multicolumn{2}{|c|}{ Globally perfect } \\
\hline & N1 & N1s & $\mathrm{N} 2 \mathrm{~s}$ & $\mathrm{~N} 3 \mathrm{~s}$ & L1 & L2 & $\mathrm{N}^{\mathrm{a}}$ & $\mathrm{L}$ \\
\hline \multirow{4}{*}{ top chord } & 0.00 & -0.27 & 0.09 & 0.13 & 0.03 & -0.08 & -0.60 & -0.66 \\
\hline & 0.00 & 0.14 & -0.01 & 0.70 & 0.05 & 0.65 & -0.29 & -0.29 \\
\hline & 0.00 & -0.34 & 0.29 & 0.78 & 0.00 & 0.33 & -0.54 & -0.89 \\
\hline & 0.00 & -0.21 & 0.46 & 1.39 & -0.32 & 0.46 & -0.29 & -1.12 \\
\hline \multirow{4}{*}{ bottom chord } & - & - & - & - & - & - & - & - \\
\hline & 0.00 & 0.05 & -0.49 & 0.19 & -0.83 & -0.09 & -0.77 & -1.11 \\
\hline & 0.00 & 0.06 & -0.59 & 0.20 & -0.65 & 0.21 & -0.92 & -0.99 \\
\hline & 0.00 & 0.07 & -0.71 & 0.23 & -0.99 & 0.02 & -1.12 & -1.38 \\
\hline \multirow{4}{*}{ truss braces } & 0.00 & -0.05 & 0.49 & -0.19 & 0.05 & -0.68 & 0.78 & 0.34 \\
\hline & 0.00 & -0.08 & 0.77 & -0.27 & 0.08 & -1.05 & 1.19 & 0.43 \\
\hline & 0.00 & -0.14 & 1.68 & -0.48 & -0.09 & -2.29 & 2.65 & 0.79 \\
\hline & 0.00 & 0.24 & -4.41 & 0.61 & -31.79 & -25.52 & -7.33 & -34.57 \\
\hline \multirow{4}{*}{ truss posts } & 0.00 & 0.05 & -0.50 & 0.18 & -0.98 & -0.28 & -0.78 & -1.24 \\
\hline & 0.00 & 0.07 & -0.76 & 0.26 & -1.81 & -0.81 & -1.17 & -2.24 \\
\hline & 0.00 & 0.09 & -1.68 & 0.38 & -4.84 & -2.58 & -2.62 & -5.48 \\
\hline & 0.00 & -0.32 & 5.13 & -0.78 & -25.36 & -32.64 & 8.56 & -22.33 \\
\hline
\end{tabular}

${ }^{\text {a }}$ But with local bow imperfection. 
using the model given in the standard EN 1993-1-1 as well as in withdrawn Polish standard PN-B-03200:1990 (Polski Komitet Normalizacyjny [PKN], 1990).

The differences in utilization ratios of the upper chord rods between the linear and non-linear models shown in Table 4 are mainly due to the fact that the bow imperfection given in the standard EN 1993-1-1 is probably adapted to the member with symmetrical cross-section in the plane of buckling, at the same time the chord of $1 / 2$ HEB220 is characterized by a small bending index in their minor axis.

In the first three panels of the truss, the axial forces in truss posts and braces the axial forces are in practical agreement in all analyzed models. Utilization ratio of all truss braces and posts in nonlinear models is also very similar, and slightly bigger in linear models with equivalent loads. The biggest differences occurs in the rods in which the internal forces are relatively small. These elements are adopted on the basis of constructional conditions and the use of their design resistance is not significant.

Differences in the forces and strains obtained from the models N1 and N1s were small. It seems, that additional effort associated with the modeling of the bottom chord deviation may be omitted, assuming that the deviation does not exceed $\Delta \theta= \pm 1 / 500 \mathrm{rad}$ (Fig. 1b).

\section{CONCLUSIONS}

In engineering practice, various types of calculation models may be used to analyze roof structures. The simplest of them, in-plane 2D model provided in the standard EN 1993-1-1, allows only to roughly estimate the forces in members of the transverse roof bracings, while the forces in vertical braces between trusses and the influence of global imperfections on the change of the internal forces in the bottom chords will not be known. Therefore, this scheme was not discussed.

The most accurate calculation model is the spatial model with geometrical imperfections - the global of the whole chords and the local of the individual rods, or with precise equivalent load mentioned in this work (Fig. 4). The limit values of global initial imperfections that are permissible in properly erected structure are defined in the standard EN 1090-2. In turn, the standard EN 1993-1-1 standard provides equivalent values of geometrical imperfections - local and global, which should be taken into account when using a non-linear or $2^{\text {nd }}$ order theory. Although these standards are linked, there is no full compatibility between them. Therefore, it would be advisable to specify which global imperfections and their values should be included in the spatial calculations of the roof structures when using the $2^{\text {nd }}$ order theory.

The method of assuming the equivalent load on the correctness of the assessment of the ultimate limit state condition in the upper chord as well as in braces and posts of trusses is not strongly decisive. On the other hand, a significant issue is omitted in the calculation of the bottom chord. Even if the bottom chord is perfectly straight, as a result of the spatial work of the whole structure, horizontal actions resulting from the truss initial twisting (due to upper chord initial global imperfection) will appear. In view of tendency of significant utilization of the load bearing capacity of steel structures in design process, the correct calculation of imperfections influence seems to be an urgent need. It seems that accepting $\Delta H_{\text {top }}$ and $\Delta H_{\text {bot }}$ loads as in the model N3s is a convenient and correct way to assess the internal forces and stresses in the bottom chords. It may be more convenient than using $q_{\mathrm{d}}$, which requires the knowledge of forces in rods from the first calculation step.

In order to obtain experimental confirmation of the calculation results, it is anticipated full scale tests on a single-storey industrial building by means of the modern methods of deformation and stress analyses (residual magnetic field - RMF and fiber Bragg glass - FBG) described e.g. by Juraszek (2018a, 2018b, 2019a, 2019b, 2019c, 2020), thereby allowing future formulation of a simple algorithm allowing for the mapping of the actual state of the spatial structure.

\section{Authors' contributions}

Conceptualization: J.Z.; methodology, validation, formal analysis, investigation: G.G., J.Z., writing - original draft preparation: J.Z.; writing - review and editing: G.G.; visualization: G.G.; supervision: G.G., J.Z.

Both authors have read and agreed to the published version of the manuscript.

\section{REFERENCES}

European Committee for Standardization [CEN] (2005). Eurocode 3: Design of steel structures. Part 1-1: General rules and rules for buildings (EN 1993-1-1). Bruxelles: European Committee for Standardization. 
European Committee for Standardization [CEN] (2018). Execution of steel structures and aluminium structures. Technical requirements for steel structures (EN 1090-2). Bruxelles: European Committee for Standardization.

Juraszek, J. (2018a). Hoisting machine brake linkage strain. Archives of Mining Sciences, 63 (3), 583-597. https:// doi.org/10.24425/123676

Juraszek, J. (2018b). Strain and force measurement in wire guide. Archives of Mining Sciences, 63 (2), 321-334. https://doi.org/10.24425/122450

Juraszek, J. (2019a). Application of fiber optic FBG techniques in analysis of strain in engineering machines. New Trends in Production Engineering, 2 (1), 480-485. https://doi.org/10.2478/ntpe-2019-0051

Juraszek, J. (2019b). Residual magnetic field non-destructive testing of gantry cranes. Materials, 12 (4), 564. https://doi.org/10.3390/ma12040564

Juraszek, J. (2019c). Residual magnetic field for identification of damage in steel wire rope. Archives of Mining Sciences, 64 (1), 7992. https://doi.org/10.24425/ ams.2019.126273

Juraszek, J. (2020). Fiber Bragg sensors on strain analysis of power transmission lines. Materials, 13 (7), 1559. https://doi.org/10.3390/ma13071559

Krajewski, M. \& Iwicki, P. (2015). Analysis of brace stiffness influence on stability of the truss. International Journal of Applied Mechanics and Engineering, 20 (1), 97-108. https://doi.org/10.1515/ijame-2015-0007

Niewiadomski, J. \& Zamorowski, J. (1987). Wpływ odkształceń giętnych na sztywność osiową prętów [The influence of flexural deformation on the axial force of rods]. In XXXIII Konferencja Naukowa KILiW PAN i KN PZITB, Gliwice, Krynica 1987: referaty (Vol. 3, pp. 63-68). Gliwice: Zakład Graficzny Politechniki Śląskiej.
Niewiadomski, L. \& Zamorowski, J. (2017). Wstępne imperfekcje łukowe $\mathrm{w}$ analizie połaciowych stężeń poprzecznych [Initial bow imperfections in transverse roof bracing analysis]. Zeszyty Naukowe Politechniki Częstochowskiej. Budownictwo, 23, 231-244. https://doi. org/10.17512/znb.2017.1.23

Piątkowski, M. (2017). Metody uwzględniania imperfekcji geometrycznych w kratownicach stalowych [The methods of consideration of geometrical imperfection in steel trusses]. Czasopismo Inżynierii Ladowej, Środowiska i Architektury - Journal of Civil Engineering, Environment and Architecture, 64 (4/I), 229-243. https://doi. org/10.7862/rb.2017.208

Polski Komitet Normalizacyjny [PKN] (1990). Konstrukcje stalowe. Obliczenia statyczne $i$ projektowanie (PN-B-03200:1990). Warszawa: Polski Komitet Normalizacyjny.

Zamorowski, J. (2013). Przestrzenne konstrukcje prętowe $z$ geometrycznymi imperfekcjami i podatnymi węzłami [Spatial bar structures with geometrics imperfections and flexible nodes]. Gliwice: Wydawnictwo Politechniki Śląskiej.

Zamorowski, J. \& Gremza, G. (2009). Advanced analysis of the load-bearing capacity of the sports hall "Saucer" in Katowice. In N. Jendzelovsky, A. Grmanova (Eds.), 7th International Conference on New Trends in Statics and Dynamics of Buildings, Bratislava, October 22-23, 2009. Conference proceedings. Bratislava: Slovak Society of Mechanics SAS.

Zamorowski, J. \& Gremza, G. (2019). Modelling of roof bracings of single-storey industrial buildings. In F. Wald, M. Jandera (Eds.), Stability and Ductility of Steel Structures 2019 (pp. 1309-1316). Leiden: CRC Press/Balkema. https://doi.org/10.1201/9780429320248

\section{PROBLEM WŁAŚCIWEGO PRZYJMOWANIA OBCIĄŻENIA ZASTĘPCZEGO W DACHU Z IMPERFEKCJAMI}

\section{STRESZCZENIE}

Przeanalizowano siły wewnętrzne i naprężenia oraz oceniono wykorzystanie nośności obliczeniowej w wybranych elementach konstrukcji dachu z lokalnymi i globalnymi imperfekcjami geometrycznymi. Wartości tych imperfekcji przyjęto na podstawie informacji podanych w normach EN 1090-2 i EN 1993-1-1. Oprócz podstawowego modelu odniesienia $\mathrm{z}$ imperfekcjami przeanalizowano modele bez imperfekcji z różnorodnymi układami obciążeń zastępczych według koncepcji własnej autorów oraz porównawczo według normy EN 1993-1-1. Obliczenia wykonano, wykorzystując analizę I i II rzędu. Przedstawiono wnioski dotyczące dokładności oszacowania sił wewnętrznych oraz sprawdzenia stanów granicznych nośności i użytkowania przy układzie obciążeń zastępczych zaproponowanym w normie EN 1993-1-1. Wykazano niedoskonałość przepisów tej normy w zakresie przyjmowania obciążeń zastępczych w konstrukcjach dachowych z imperfekcjami, która prowadzi do niedoszacowania naprężeń w pasie dolnym wiązara.

Słowa kluczowe: imperfekcje kratownic, obciążenie zastępcze, analiza II rzędu, stan graniczny 